\title{
The Role of Antimicrobial Peptides at the Ocular Surface
}

\author{
Alison M. McDermott \\ College of Optometry, University of Houston, Houston, Tex., USA
}

\section{Key Words}

Defensin · Cathelicidin · LL-37 • Infection • Wound healing

\begin{abstract}
Antimicrobial peptides (AMPs) such as defensins and cathelicidins are small peptides with broad-spectrum activity against bacteria, fungi and viruses. In addition, several AMPs modulate mammalian cell behaviours including migration, proliferation and cytokine production. This review describes findings from recent studies showing the presence of various AMPs at the human ocular surface and discusses their mechanism of antimicrobial action and potential nonmicrobicidal roles. Corneal and conjunctival epithelial cells produce $\beta$-defensins and the cathelicidin LL-37, whereas neutrophils, infiltrating in response to a specific stimulus, supply additional LL-37 as well as $\alpha$-defensins. In vitro studies suggest that LL-37 and human $\beta$-defensin- 3 are the most likely to have significant independent antimicrobial activity, while other AMPs may act synergistically to help protect the ocular surface from invading pathogens. Current evidence also supports a role for some AMPs in modulating wound healing responses. Although yet to be brought to fruition, AMPs hold significant potential as therapeutic agents for the prophylaxis and treatment of infection, promotion of wound healing and immune modulation.
\end{abstract}

Copyright $\odot 2008$ S. Karger AG, Basel

\section{Introduction}

Antimicrobial peptides (AMPs) are effectors of innate immunity in both plants and animals. They are small peptides, most consisting of less than 50 amino acids, are amphipathic and typically carry an overall positive charge ( +2 or greater) due to a relative excess of amino acids such as arginine and lysine. They have been found in every species examined to date and over 900 have been identified across species. The peptides show a broad spectrum of antimicrobial activity and many have additional effects on mammalian cell behaviours.

The primary sources of mammalian AMPs are immune and inflammatory cells, particularly neutrophils, and epithelial tissue. The two major categories of mammalian AMPs are the defensins and cathelicidins. Human defensins are 29-45 amino acids in length and are characterized by the presence of 6 cysteine residues that interact to form 3 disulphide bonds and a $\beta$-sheet structure. There are two classes of human defensin, referred to as $\alpha$ and $\beta$, based upon different patterns of connectivity of the cysteines; the $\alpha$-defensin arrangement is C1-C6, $\mathrm{C} 2-\mathrm{C} 4$ and $\mathrm{C} 3-\mathrm{C} 5$, whereas that of the $\beta$-defensins is $\mathrm{C} 1-$ C5, C2-C4 and C3-C6 [1]. A third defensin class, referred to as theta (or minidefensins), has been identified in leukocytes of non-human primates [2-4]. These 18-amino acid peptides are formed by the splicing of 2 truncated $\alpha$-defensins to create a circular structure. Six genes for human $\theta$-defensins have been identified, but premature stop codons prevent their translation [5].

Alison M. McDermott

University of Houston, College of Optometry

505 J Davis Armistead Bldg, 4901 Calhoun Road

Houston, TX 77204 (USA)

Tel. +1 713743 1974, Fax +1 713743 2053, E-Mail amcdermott@optometry.uh.edu 
Six human $\alpha$-defensins and $4 \beta$-defensins have been identified and characterized. Of the $6 \alpha$-defensins, 4 were discovered in neutrophils, hence were named human neutrophil peptide (HNP)-1 to -4 [6-8]. Mature HNP-1 to -4 are localized to a subset of azurophil (myeloperoxidase-specific) granules where they represent $30 \%$ of total granule protein content $[9,10]$. HNP-1 and -3 differ only in the first amino acid and HNP-2 is believed to be a proteolytic product of HNP-1 and/or -3 [7]. HNP-4 differs significantly in amino acid sequence from the other HNPs and is a minor component of the neutrophil granules [8]. HNPs are synthesized as preprosequences consisting of an amino terminal signal sequence (approximately 19 amino acids), an anionic propiece (approximately 45 amino acids) and a C-terminal mature peptide $[11,12]$. The propiece is required for correct sub-cellular trafficking and sorting of proHNPs and acts as an intramolecular inhibitor of HNP activity presumably through charge neutralization [13-15]. Whilst the major activity of HNPs is presumed to occur when the azurophil granules fuse with the phagocytic vacuole containing ingested pathogen, HNPs are released extracellularly upon neutrophil activation and can be detected in plasma and body fluids [10]. Although neutrophils are the primary source of HNPs, these $\alpha$-defensins have also been localized to monocytes and lymphocytes and immature monocyte-derived dendritic cells $[16,17]$. Also, recently it was reported that macrophages can acquire HNPs and other antimicrobial substances through phagocytosis of apoptotic neutrophils [18].

The other 2 characterized $\alpha$-defensins are human defensin (HD)-5 and -6, which were first isolated from intestinal Paneth cells $[19,20]$. HD-5 has now also been localized to the female reproductive tract and is found 'infrequently' in nasal and bronchial epithelial cells [21, 22]. The intestinal defensins are stored in the Paneth cells in proforms, which are then cleaved, during or perhaps after their release into the intestinal lumen. Processing is carried out by the serine proteinase trypsin, which is also produced by the Paneth cells as an inactive zymogen [23].

The genes for the $\alpha$-defensins reside on chromosome 8p23 [24]. The genes for HNP-1 to - 4 have 2 introns and 3 exons, with the last 2 exons encoding the prepropeptide [25]. In contrast, the genes for HD-5 and -6 have only 2 exons $[25,26]$. Several studies have shown copy number polymorphisms in the genes DEFA1 and DEFA3, which code for HNP-1 and HNP-3, respectively, with some people having up to 14 copies and others none [27-30]. This raises the question of whether or not variability in gene copy numbers may result in differences in individual resistance to infection. The genes for the other $\alpha$-defensins are only found as 2 copies per diploid genome [29].

The 4 characterized human $\beta$-defensins are named human $\beta$-defensin (hBD)-1 to - 4 . They are primarily expressed in epithelial tissue, but some (hBD-1 and -2) have also been found in immune cells (monocytes, macrophages and dendritic cells) [31,32]. hBD-1, which was first isolated from plasma, is constitutively expressed by a variety of epithelia including airway epithelia, urogenital tissue, nasolacrimal duct and mammary gland [3337]. hBD-2 expression is inducible in many epithelia in response to bacterial products [often acting via toll-like receptor (TLR) activation] and cytokines [38-41]. hBD-3 expression is also inducible in some epithelial tissues by tumour necrosis factor (TNF)- $\alpha$ and interferon- $\gamma[42$, 43]. The expression of hBD- 4 is more restricted than that of the other defensins, with testes and epididymis having the highest levels $[44,45]$. Expression of hBD-4 is inducible by bacterial exposure but not by the cytokines reported to upregulate hBD-2 and -3 [44].

Like $\alpha$-defensins, the $\beta$-defensins also arise by cleavage of a larger precursor, this time consisting of a leucinerich signal sequence, a short or absent propiece and the mature peptide. In most cases the $\beta$-defensin precursors are encoded in 2 separate exons separated by an intron of variable length, with one exon encoding the signal sequence and propiece and the other encoding the mature peptide. The gene for hBD-2 has 3 binding sites for nuclear factor (NF) $-\kappa B$ and binding sites for other transcription factors such as activator protein-1 and NF for interleukin (IL)-6 (NF-IL-6), which is in keeping with its status as an inducible AMP [46-48].

The genes for hBD-1 to -4 (known as DEFB1, DEFB4, DEFB103 and DEFB104, respectively) all map to chromosome 8 p22-23 close to the $\alpha$-defensin genes [49]. Using computational search strategies it has been established that the human genome contains some $39 \beta$-defensin genes and pseudogenes that are distributed in 5 clusters, 2 each on chromosomes 8 and 20 and 1 on chromosome $6[50,51]$. Only a few of these novel genes have been investigated. For example, Yamaguchi et al. [45] studied DEFB5 and 6 and found that their products, named hBD-5 and -6 , were expressed in the epididymis. DEFB25-29 and 118 are also expressed in the male genital tract $[52,53]$. Premratanachai et al. [54] observed that DEFB7, 9, 11 and 12 were constitutively expressed by gingival keratinocytes, whereas expression of DEFB8 and 14 was induced by cytokines and infection. hBD-5 and the product of DEFB9 have also been found to be expressed in the lung [55]. 
As with the $\alpha$-defensins, copy number variation has been reported for hBD-2, -3 and -4, with up to 12 copies per diploid genome being reported $[29,56]$. Gene copy number correlated with expression, suggesting that these variations may have significant consequences for the functioning of the immune system. DEFB1, the gene for hBD-1, only appears as a single copy but exhibits a number of single nucleotide polymorphisms which have been linked to a variety of disease conditions including chronic obstructive pulmonary disease, asthma, cancer and endophthalmitis $[29,57-60]$.

The second major group of mammalian AMPs is the cathelicidins, and while several species such as cow and pig express multiple cathelicidins only one, LL-37, is expressed in humans. The term cathelicidin was coined by Zanetti et al. [61] to describe AMPs that have a 'cathelin precursor' domain, the sequence of which is very similar to that of cathelin, a protein in porcine neutrophils which is an inhibitor of the cysteine protease cathepsin L (i.e. cathepsin $\underline{\mathrm{L}}$ inhibitor) [62]. The N-terminal cathelin domain is highly conserved among species and is 99-114 amino acids long [61]. In contrast, the C-terminal antimicrobial domain varies considerably in sequence and length (12-100 amino acids). Identified by three independent groups in 1995, the human cathelicidin LL-37 is so called because it begins with 2 leucine residues and is 37 amino acids long [63-65]. The gene for LL-37, CAMP, maps to chromosome 3 and exists as a single copy $[66,67]$. It has 4 exons, the first 3 of which code for a 29 -amino acid signal sequence and the cathelin domain, with the 4 th coding for the mature peptide [68]. The full-length precursor is referred to as human cationic antimicrobial protein 18 (hCAP18) owing to its mass $(18 \mathrm{kDa})$ and similarity to the rabbit antimicrobial protein CAP18 [64, 69].

Initially, LL-37 was isolated from neutrophils, where it is stored as hCAP18 in the secondary (or specific) granules. Processing of hCAP18 to yield LL-37 occurs during its secretion and is mediated by proteinase 3 [70]. In addition to neutrophils, LL-37 is now known to be produced by immune cells, mast cells and a variety of epithelia including lung, skin, squamous epithelia of mouth, tongue, esophagus, cervix and vagina and eccrine sweat glands $[16,71-75]$. LL-37 expression is constitutive in some tissues but inducible by pathogens, pro-inflammatory cytokines and vitamin D3 in others [76-78]. Regulatory motifs involved in mediating LL-37 upregulation likely include NF- $\kappa$ B, interferon- $\gamma$ response element and NF-IL-6 [66]. Notably, while the parent molecule hCAP18 has no known biological activity, in addition to LL-37, the cathelin domain has also been shown to be active, as it has antimicrobial activity and inhibits proteases [79]. Post-secretory processing of LL-37 by the serine proteases kallikrein 5 and 7 has been shown to occur at the skin surface, generating smaller peptides (referred to as KR-20, KS-30 and RK-31) with greater antimicrobial activity than the parent molecule $[80,81]$.

While defensins and cathelicidin represent the most well characterized human AMPs, a number of others have been identified. Liver expressed antimicrobial peptide (LEAP)-1 was identified in blood ultrafiltrate by Krause et al. [82] in 2000. This 25-amino acid peptide has 4 disulphide bonds and is highly expressed in liver (hence its name). It was also isolated from urine by Park et al. [83], who referred to is as hepcidin. A second AMP that is also synthesized by the liver, LEAP-2, has also been isolated from blood [84]. Several circulating forms were identified which differed in length but which all had 2 disulphide bonds. Hepcidin (LEAP-1) is now recognized as a peptide hormone important for iron homeostasis and through this action may further contribute to host defence by limiting iron availability to microbes [85]. Dermcidin is a 47-amino acid AMP expressed in sweat glands and secreted into sweat [86]. Histatins are a group of histidine-rich AMPs produced by the parotid and sub-mandibular salivary glands, and in contrast to most other AMPs, which are bactericidal, these peptides are primarily antifungal [87]. Thymosin $\beta-4$, a $\mathrm{G}$ actin-sequestering anionic peptide, has also been shown to have antimicrobial activity and is present in platelets and various tissues [88]. A significant number of chemokines, including macrophage inflammatory protein (MIP)-3 $\alpha$, CCL1, CXCL1-3 and CXCL9-11, have also been found to have antimicrobial activity $[89,90]$. However, for molecules such as these, microbial killing is unlikely to be their major activity in vivo. Other small peptides with antimicrobial activity are discussed in a recent review by Radek and Gallo [91].

\section{AMPs Present at the Ocular Surface}

As summarized in table 1, the major AMPs present at the ocular surface are defensins and LL-37. In regard to defensins, both $\alpha$ - and $\beta$-defensins have been detected, with the primary source of the former being infiltrating neutrophils, whilst the latter are synthesized and secreted by ocular surface epithelial cells. Gottsch et al. [92] detected $\alpha$-defensins HNP- 1 to -3 in human corneal stroma in cases of rejected transplants and post-infectious kera- 
Table 1. Summary of AMPs present at the human ocular surface

\begin{tabular}{|c|c|c|c|}
\hline AMP & Source & $\begin{array}{l}\text { Level detected } \\
\text { (mRNA/protein) }\end{array}$ & $\begin{array}{l}\text { Activity against ocular } \\
\text { surface pathogens }{ }^{1}\end{array}$ \\
\hline \multicolumn{4}{|l|}{$\alpha$-Defensins } \\
\hline HNP-1 & \multirow{3}{*}{$\begin{array}{l}\text { neutrophils infiltrating ocular surface } \\
\text { and in tear film }\end{array}$} & \multirow[t]{3}{*}{ protein } & \\
\hline HNP-2 & & & \\
\hline HNP-3 & & & \\
\hline \multicolumn{4}{|l|}{$\beta$-Defensins } \\
\hline hBD-1 ) & \multirow{3}{*}{$\begin{array}{l}\text { corneal and conjunctival epithelial cells } \\
\text { ( } 1 \text { and } 3 \text { constitutive, } 2 \text { inducible) }\end{array}$} & \multirow[t]{3}{*}{ mRNA and protein } & \multirow{4}{*}{$\begin{array}{l}\text { weak PA, none Staph } \\
\text { strong PA, weak Staph } \\
\text { strong PA and Staph }\end{array}$} \\
\hline hBD-2 & & & \\
\hline hBD-3 & & & \\
\hline DEFB109 & corneal and conjunctival epithelial cells & mRNA & \\
\hline \multicolumn{4}{|l|}{ Cathelicidin } \\
\hline LL-37 & $\begin{array}{l}\text { neutrophils infiltrating ocular surface and in tear film; } \\
\text { corneal and conjunctival epithelial cells (inducible) }\end{array}$ & mRNA and protein & strong PA and Staph \\
\hline \multicolumn{4}{|l|}{ Others } \\
\hline $\mathrm{MIP}-3 \alpha$ & corneal and conjunctival epithelial cells & mRNA and protein & weak PA and Staph \\
\hline Thymosin $\beta-4$ & corneal and conjunctival epithelial cells & mRNA and protein & weak PA and Staph \\
\hline LEAP- 1 and -2 & corneal and conjunctival epithelial cells & mRNA & \\
\hline Histatins & tear film & protein & \\
\hline Statherin & cornea and conjunctiva & mRNA & \\
\hline CCL28 & cornea and conjunctiva & mRNA & \\
\hline CXCL-1 & inflamed cornea & mRNA & \\
\hline
\end{tabular}

\footnotetext{
${ }^{1}$ Comparisons are based on published data comparing activity of AMPs against specific strains of P. aeruginosa (PA) and S. aureus and epidermidis (Staph) in vitro.
}

titis but not normal cornea. Haynes et al. $[93,94]$ also observed positive immunoreactivity for HNP-1 to -3 in inflamed conjunctiva and samples of normal tear film. Recently, Zhou et al. [95] confirmed the presence of HNP1 to -3 in tear film and using liquid chromatographymass spectrometry showed that the normal levels of these defensins were in the range of $0.2-1 \mu \mathrm{g} / \mathrm{ml}$. Elevated tear levels of $\alpha$-defensins were noted in patients after surgery for removal of an ocular surface neoplasm and in allergic patients with corneal epithelial lesions [95, 96]. Expression of the $\alpha$-defensins HD- 5 and HD- 6 has also been investigated; however, no evidence for their production was found $[93,94]$.

Both cornea and conjunctival epithelial cells express $\beta$-defensins. hBD-1 is constitutively expressed, whereas the expression of hBD-2 is variable, as it is expressed by normal tissue only occasionally [93, 94, 97-101]. Ocular surface hBD-2 expression is known to be inducible by exposure to both Gram-negative and -positive bacteria and bacterial products such as lipopolysaccharide (LPS), peptidoglycan and lipoproteins [78, 98, 102-104]. These ef- fects are chiefly mediated via activation of TLRs such as TLR2 [78]. Cytokines such as IL-1 and TNF- $\alpha$ have also been shown to induce hBD-2 [100, 101, 105]. Expression of this defensin is also upregulated in the cornea in response to injury [106] and in the conjunctival epithelium of patients with dry eye $[101,107]$. Corneal and conjunctival epithelial cells also express hBD-3 [100, 101, 108], but while some studies have indicated that expression of this defensin is inducible by TNF- $\alpha$ and interferon- $\gamma[42,43$, 109], this was not observed in ocular surface epithelial cells [101]. Whilst McIntosh et al. [108] detected expression of hBD-4 in cultured ocular surface cells, this defensin was found only infrequently in non-cultured samples. Huang et al. [110] did not detect hBD- $4,-5$ or -6 in ocular surface cells. McIntosh et al. [108] also studied the expression of 13 putative novel $\beta$-defensin genes (DEFB105, $107,108,118-123,125-127,129)$ in ocular surface tissue but did not find them to be present. In a recent study, expression of a novel $\beta$-defensin gene, DEFB109, was detected in the ocular surface epithelia, and interestingly its expression was decreased in inflammation and infection 
[111]. It should also be noted that in contrast to the $\alpha$-defensins, $\beta$-defensins have not been detected in the tear film $[95,112]$.

LL-37, the only member of the human cathelicidin family, is also expressed by both corneal and conjunctival epithelial cells $[108,113]$. Its expression is increased in response to corneal epithelial injury and bacterial challenge with Pseudomonas aeruginosa and Staphylococcus aureus $[78,102,114]$. Also, as LL-37 is a major component of neutrophil granules, its ocular surface levels are also expected to rise in situations leading to infiltration of these and other inflammatory cells.

While defensins and LL-37 represent the main AMPs present at the ocular surface, others have been reported. McIntosh et al. [108] noted expression of mRNA for LEAP-1 and -2, although this could not be confirmed by Huang et al. [110]. Also, Martins et al. [115] recently reported expression of dermcidin at the protein level in corneal epithelium [pers. communication] and endothelium, although this contradicts earlier mRNA expression data of McIntosh et al. [108]. Statherin [116], an antimicrobial phosphoprotein, and CCL28 and CXCL-1 [117], 2 of many 'antimicrobial cytokines' $[89,90]$, are also expressed by ocular surface epithelial cells. Huang et al. [110] reported that corneal and conjunctival epithelial cells express MIP-3 $\alpha$ and thymosin $\beta-4$. However, whilst both of these peptides have been reported to have antimicrobial activity, they were not particularly effective against ocular pathogens. Antifungal histatins have been detected in tear film, but are not expressed by ocular surface epithelia $[110,118]$.

While the epithelia have been the major focus for studies on ocular surface AMP expression, immune and inflammatory cells normally residing in the cornea and conjunctiva or drawn in in response to inflammatory stimuli are also sources of various AMPs. Additionally, defensins and cathelicidin have recently been detected in glands of Moll, and thus may enter the tear film via this route [119].

\section{General Mechanisms of Antimicrobial Action}

As a group, AMPs demonstrate direct broad-spectrum antimicrobial activity against a wide range of bacteria, fungi and some viruses. Peak antibacterial activity typically occurs in the low micromolar range, although there is significant variability in the ability of AMPs to kill specific bacteria. In vitro antimicrobial activity is rapid (15-90 $\mathrm{min}$ ), and maximal effects are most com- monly observed under conditions of low ionic strength, with low concentrations of divalent cations and plasma proteins, although some AMPs, including hBD-3, are less salt sensitive than others, likely attributable to an increased positive surface charge [120]. A recent study by Dorschner et al. [121] suggests that carbonate is a critical ionic factor present in vivo that allows AMPs to exert significant antimicrobial activity.

The primary site of AMP action is the microbial cell membrane, electrostatic disruption of which leads to permeabilization, loss of essential intracellular components and death. The preference of AMPs for microbial versus mammalian cell membranes is due to differences in membrane components which result in the surface charge of mammalian cells being neutral whereas bacteria are negatively charged. In addition, cholesterol, which is present in mammalian but not bacterial cell membranes, makes it more difficult for AMPs to disrupt the bilayer $[122,123]$. It should be noted, however, that, whilst many AMPs show a preference for prokaryotic cells and do not affect mammalian cells, several, particularly at high concentrations, are cytotoxic to eukaryotic cells.

Antimicrobial effectiveness is influenced by a number of factors including amino acid sequence (content and length), net positive charge, amphipathicity, hydrophobicity, folding and oligomerization. A number of different mechanisms have been proposed, but all have electrostatic interaction between the positively charged AMP and the negatively charged microbial membrane as the initial interaction. In the carpet model, AMPs, either as single molecules or oligomers, first assemble as a covering on the surface of the membrane [124]. Such 'carpeting' may also precede some of the other putative modes of permeabilization discussed below. The AMP molecules orient themselves so that the hydrophobic portion is towards the membrane lipids and the hydrophilic region faces the polar head groups of the phospholipids. On reaching a threshold concentration, the bilayer curvature is disrupted, there is thinning of the outer leaflet and thus the membrane is permeated. Transient holes may also be present before the collapse of the membrane.

In the barrel-stave model, peptides form traditional ion channel pores, with the peptides forming the staves. In order to achieve this, peptides must be hydrophobic to enable penetration of the membrane, they have to be able to self-assemble while associated with the membrane and if $\alpha$-helical (such as LL-37) must be at least 22 amino acids in length or 8 amino acids if they have a $\beta$-sheet arrangement (such as the defensins). The peptides aggregate in the membrane so that hydrophobic regions align with the 
lipid with the hydrophilic regions forming the interior of the pore. Recruitment of additional monomers leads to a steady increase in pore size, and leakage of intracellular components subsequently leads to cell death [125].

In the toroidal pore (also referred to as wormhole) model, the AMPs insert into the membrane and cause the monolayers to bend through the pore so that the interior is lined with both AMPs and lipid head groups [126]. Interactions between the positively charged peptides are minimized due to the negatively charged phospholipids lining the pore. This model differs from the barrel-stave model as the peptides are always associated with the lipid head groups even when inserted into the membrane in a perpendicular fashion [127].

Other proposed mechanisms include the detergent model, where the AMPs carpet the membrane, ultimately reaching a high enough local concentration that allows them to act as detergents and break the membrane into smaller fragments [128]. In the sinking raft model, the binding of AMPs creates a large membrane curvature, making the AMPs sink and form transient pores [129]. There is also the molecular electroporation model, where AMPs create a difference in electrical potential in the membrane, leading to pore formation [130].

There is also evidence to suggest that several AMPs utilize intracellular targets in addition to (or sometimes instead of) membrane permeabilization to effect bacterial killing. These mechanisms include inhibition of protein, peptidoglycan and nucleic acid synthesis and interference with the activity of bacterial heat shock proteins [131-139]. These modes of AMP 'intracellular killing' are reviewed in detail by Brogden [140] and Hale and Hancock [141].

Studies are still ongoing to determine the precise mechanism of antimicrobial action of the human AMPs. Defensins form dimers in solution, and Wimley et al. [142] reported that neutrophil defensin HNP-2 formed pores of up to $2.5 \mathrm{~nm}$ in diameter (possibly representing a hexamer of dimers) in unilamellar vesicles. In contrast, studies by Hoover et al. [143] indicated that while hBD-2 forms dimers, the structural and electrostatic properties of its oligomers were compatible with the carpet model rather than the formation of bilayer-spanning pores. While the details of defensin action have still to be elucidated, it is known that disulphide bonding is not required for defensin antimicrobial activity $[144,145]$. Interestingly, the activity of hBD-3 against Gram-negative organisms appears to reside in the $\mathrm{C}$-terminal region, whereas that against Gram-positives and fungi resides in the $\mathrm{N}$ terminal region [145]. In contrast to most other linear
AMPs, LL-37 assumes a secondary structure and forms oligomers in aqueous solution [147, 148]. Biophysical studies of its mechanism of antimicrobial action were recently reviewed in detail by Durr et al. [149]. While the barrel-stave and detergent-like mechanisms have been ruled out for LL-37, nuclear magnetic resonance studies provide supportive evidence for the toroidal-pore mechanism [150], while others favour the carpet model [148, 151]. Interestingly, the results of a recent study suggest that LL-37 utilizes different mechanisms of membrane perturbation depending upon the head group charge and hydrocarbon chain length of the lipids [152]. The antimicrobial activity of LL-37 resides in the C-terminal region, with a 13-residue core peptide consisting of amino acids 17-29 having the most activity [153].

Mechanisms of AMP antibacterial activity are the most well characterized to date; however, several AMPs, including defensins and LL-37, have antifungal (candidacidal) and antiviral (for example herpes simplex, adenovirus and human immunodeficiency virus) activity [154159]. Antifungal activity has several mechanistic similarities to antibacterial activity including membrane permeabilization by some AMPs and interference with mitochondrial function [160]. Antiviral activity may include direct effects such as interference with viral envelopes or may be indirect through effects on host target cells such as modulation of viral co-receptor expression [161].

\section{Do AMPs Exert Antimicrobial Activity at the Ocular Surface?}

In vitro studies have shown that some AMPs known to be expressed at the ocular surface are active against common ocular pathogens. hBD-3 and LL-37 have good activity against both $P$. aeruginosa and $S$. aureus, while hBD-2 has good activity against $P$. aeruginosa but is much less effective against $S$. aureus strains. hBD-1 is the least effective of the ocular surface defensins tested, having only moderate activity against $P$. aeruginosa and none against staphylococcal strains [110, 113]. LL-37 and defensins also have activity in vitro against herpes simplex virus-1 and adenovirus 19, a major cause of conjunctivitis [113]. One issue regarding AMP activity that has frequently been raised is whether or not sufficiently high levels can be achieved in vivo to ensure adequate antimicrobial activity. This applies only to secreted AMPs, as those sequestered in neutrophil granules, for example, are known to be at concentrations greatly in excess of 
those needed for antimicrobial activity. The amount of AMPs produced by the ocular surface epithelia is unknown. Zhou et al. [95] quantitated HNPs in the tear film and found them to occur at concentrations of around 0.2$1 \mu \mathrm{g} / \mathrm{ml}$ under normal circumstances, rising to as much as $20 \mu \mathrm{g} / \mathrm{ml}$ after ocular surface surgery. The latter concentration would be expected to result in mild to moderate bacterial killing depending on the strain. Studies have revealed that in skin, defensins and LL-37 are localized to structures called lamellar bodies, which are lipid-containing vesicles secreted into the extracellular space and which have the effect of raising the local concentration of these AMPs $[162,163]$. Therefore, a similar principle operating at the ocular surface within the environment of the tear film and epithelia may be able to raise local AMP concentrations to very effective levels.

As noted earlier, the primary mechanism of AMP activity involves an electrostatic interaction with the negatively charged microbial surface. This can be disrupted by physiological salt concentrations leading to a reduction in AMP activity and an overall increase in the amount of AMP required to obtain a significant antimicrobial effect. Given that the ocular surface is bathed in a salt solution, i.e. the tear film, the antimicrobial effectiveness of AMPs in vivo is further in doubt. The effect of physiological salt concentrations and human tears on AMP antimicrobial activity has been tested in vitro. In keeping with observations of others on the effects of salt, Huang et al. [110, 114] found that antimicrobial activity was markedly reduced or even lost at low AMP concentrations but at higher concentrations it was not as greatly affected. This implies that elevated AMP levels would indeed have significant antimicrobial activity. However, it must be noted that at high concentrations AMPs frequently become cytotoxic to mammalian cells including those of the ocular surface [114]; thus, elevating levels to kill pathogens may be at the cost of some host cells. Of the ocular surface-expressed peptides tested, hBD-3 and LL-37 were least affected by salt, which is in keeping with earlier observations $[42,120]$. Synergistic interactions between AMPs and also other host defence proteins such as lysozyme have been observed and these have been shown to help temper the effects of high salt [164-166].

Interestingly, in the presence of human tears the in vitro antimicrobial activity of hBD-1 and hBD-2 was virtually eliminated even at high peptide concentrations [110]. This indicated that some component other than salt must also be responsible for inhibiting antimicrobial activity. This was further investigated for hBD-2, leading to the finding that the mucin MUC5AC, the major gel-forming mucin of the tear film, is able to bind and inhibit hBD-2 antimicrobial activity [112]. Notably, while the antimicrobial activity of hBD-1 and -2 was markedly inhibited by tears, this was not the case for LL-37 and hBD-3 [110, 114].

Overall, current in vitro studies imply that the AMPs most likely to show significant independent antimicrobial activity at the ocular surface in vivo are LL-37 and hBD-3. Others such as hBD-1 and - 2 may contribute under conditions when high concentrations can be achieved (perhaps at the risk of some cytotoxicity) and/or by interacting synergistically with AMPs and other antimicrobial molecules, or, as detailed below, their primary activities may be non-microbicidal in nature.

Having acknowledged that there are physiological issues that question the existence of AMP activity at the ocular surface, there is compelling evidence from recent animal studies to support an antimicrobial role for some AMPs in vivo. Huang et al. [167] observed that mice in which the gene Cnlp, which codes for CRAMP, the murine homologue of LL-37, had been knocked out showed increased susceptibility to $P$. aeruginosa infection, as manifested by delayed bacterial clearance, increased numbers of neutrophils, an altered cytokine profile, increased clinical scores and a failure to resolve the infection. Mice deficient in TLR4 have also been shown to be susceptible to $P$. aeruginosa keratitis, attributable in part to reduced production of antimicrobial molecules including murine $\beta$-defensin-2 [168]. Also, in a recent study it has been reported that pre-treatment with the TLR5 agonist flagellin reduces inflammation and improves outcome in a murine model of $P$. aeruginosa keratitis [169]. This effect was attributable in part to upregulation of antimicrobial molecules including CRAMP, resulting in more rapid bacterial clearance. Together these studies are the first to indicate that some AMPs are indeed able to overcome issues such as concentration, salt sensitivity and inactivation by tear film components and contribute to the defence of the ocular surface in vivo.

\section{Non-Antimicrobial Roles of AMPs at the Ocular Surface}

Evidence from a large number of studies supports roles for AMPs in a range of activities in addition to direct antimicrobial action. Such effects range from stimulation of mammalian cell proliferation to modulation of complement pathways (summarized in fig. 1). These activities are independent of AMP antimicrobial activity, typically 


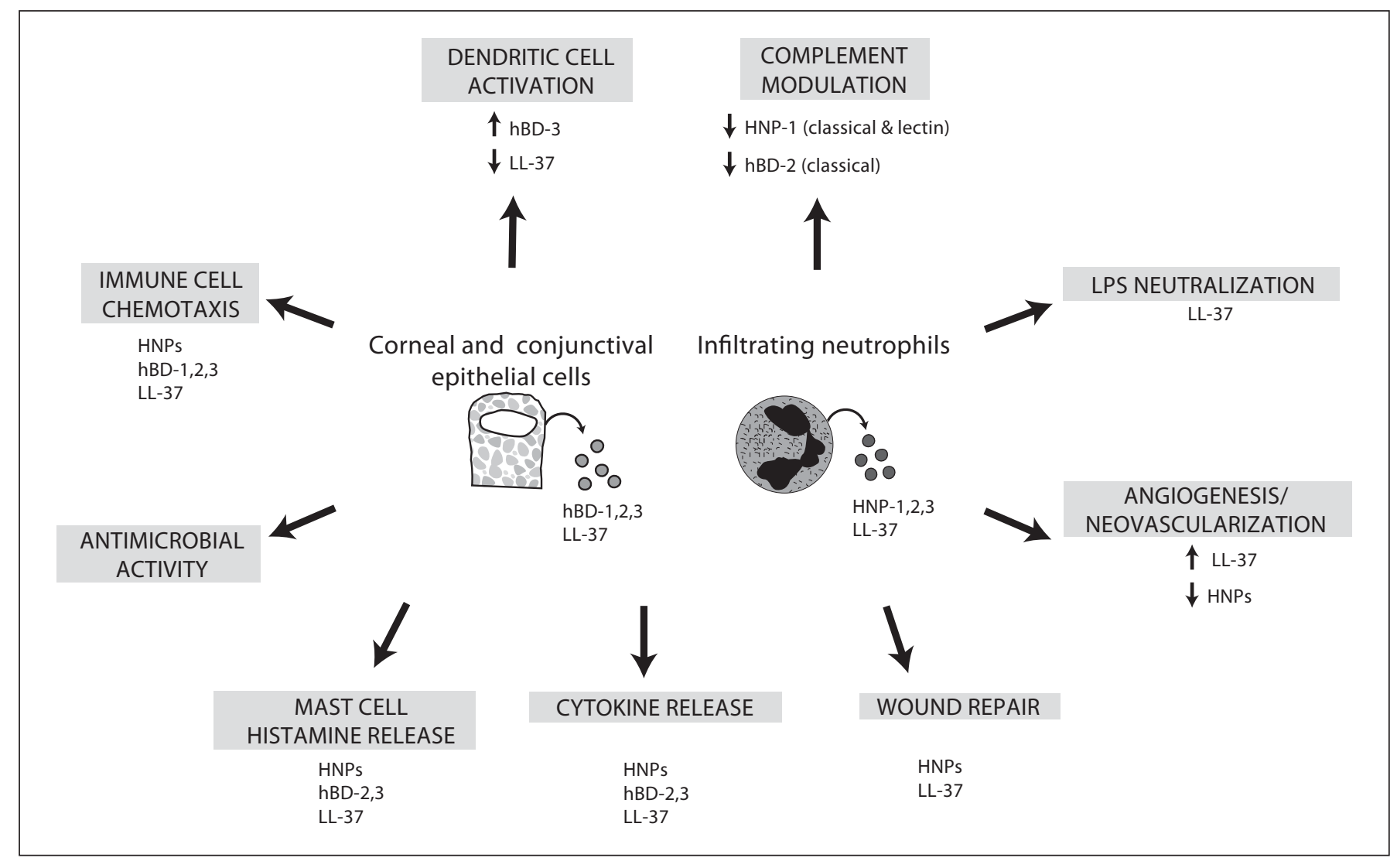

Fig. 1. Summary of possible roles for AMPs at the ocular surface. AMPs from two major sources, the corneal and conjunctival epithelial cells and infiltrating neutrophils, may participate in a number of activities in addition to direct microbial killing. The diagram is based largely on findings with other cells and tissues as few ocular surface studies have been performed. Current in vitro evidence does support a role for HNP-1, hBD-2 and LL-37 in the modulation of ocular surface wound healing.

occurring at much lower concentrations, are not sensitive to the effects of physiological salt concentrations and are receptor mediated. Specific receptors identified for defensins include P2Y6 for HNP-1 [170, 171], CCR6 for hBD-2 [172, 173] and TLR1 and -2 for hBD-3 [174], whereas LL-37 has been reported to utilize formyl peptide receptor-like 1 [16, 175-177], epidermal growth factor receptor [178] and P2X7 [179, 180]. Some studies have now begun to address non-microbicidal roles for AMPs at the ocular surface.

After corneal injury, epithelial expression of hBD-2 and LL-37 is upregulated [106, 114], and neutrophils (a source of both $\alpha$-defensins and LL-37) are known to infiltrate the ocular surface. Notably, in a rabbit model of corneal injury, levels of $\alpha$-defensins in the tears correlated with wound closure [181]. Such observations have led to the suggestion that defensins and LL-37 may be im- portant for ocular surface wound healing. Accurate and timely wound healing requires rapid cell migration, proliferation and secretion of a plethora of cytokines and growth factors [182]. Recent studies have shown that AMPs can modulate some of these activities. Huang et al. [114] showed that LL-37 stimulated migration of cultured corneal epithelial cells but, in contrast to findings in other cell types [183, 184], was not capable of promoting cell proliferation. This AMP also stimulated human corneal epithelial cells to secrete IL-1 $\beta$, IL-6, IL- 8 and TNF- $\alpha$. These actions were mediated via the $G$ protein-coupled receptor formyl peptide receptor-like 1 and transactivation of the epidermal growth factor receptor leading to activation of MAP kinase (ERK1/2 and c-JNK), phosphatidyl inositol 3 kinase and tyrosine kinase pathways. Defensins (HNP-1 and hBD-2) were shown to enhance fibronectin-induced corneal epithelial cell migration al- 
though they did not stimulate IL- 8 release by these cells [185]. In human conjunctival epithelial cells, HNP-1 transiently increased cytokine (IL-1, IL-6, IL-8 and TNF- $\alpha$ ) mRNA expression and high concentrations of hBD-2 markedly stimulated IL- 6 and IL- 8 secretion $[186,187]$. Neither defensin had a mitogenic effect on conjunctival epithelial cells, which is in contrast to conjunctival fibroblasts, where both HNP-1 and hBD-2 stimulated proliferation as determined by bromodeoxyuridine incorporation [188]. The latter effect was found to be mediated via activation of p42/44 MAP kinase and Akt. Furthermore, while defensins did not stimulate conjunctival fibroblast migration, HNP-1 and hBD-2 enhanced collagen gene expression, reduced collagen I secretion and modulated matrix metalloproteinase expression.

These studies suggest that defensins and LL-37 may directly affect wound healing by modulating cell migration and/or proliferation and may act indirectly via cytokine production. As IL-8 is a potent chemoattractant for neutrophils they may indirectly promote infiltration of these cells, lack of which has been shown to impede ocular surface healing $[189,190]$. Additionally, defensin effects on fibroblast collagen production and matrix metalloproteinase expression are suggestive of a role in tissue remodeling.

Extrapolating from findings in other cells and tissues, AMPs may also be involved in a variety of other activities at the ocular surface. LPS (endotoxin) is a product of Gram-negative bacteria and through activating TLR4 induces an inflammatory response and likely mediates much of the ocular surface damage that results from infections with pathogens such as $P$. aeruginosa. LL-37 is known to bind and neutralize LPS $[65,69]$ and so may have a role in dampening LPS-mediated ocular surface inflammation and damage. Some defensins have been observed to inhibit the classical and in some cases also the lectin pathway of complement activation [191193]. The complement pathway is active at the ocular surface [194], therefore again, some AMPs may exert an anti-inflammatory role by dampening complement activation. It should be noted, however, that one group has reported that $\alpha$-defensins activate the classical complement pathway [195]. If this activity were to predominate, a pro-inflammatory effect would result, although enhanced microbial killing would be a potential benefit [196]. Defensins and LL-37 have also been shown to stimulate mast cell degranulation $[197,198]$ and thus may contribute to conjunctival mast cell activation and so provide an additional route leading to inflammatory responses.
It was believed for many years that corneal immune privilege was in part due to a lack of immune cells, but it is now well established that the cornea, along with the conjunctiva, is well equipped with leukocytes and in particular antigen-presenting cells such as dendritic cells [199]. The immune privilege results from these cells (particularly those in the central cornea) being in an immature rather than mature active state under normal circumstances. Both defensins and LL-37 have been shown to be chemotactic for a variety of immune and inflammatory cells, including lymphocytes, monocytes and immature dendritic cells, and thus may help draw these cells to a site of injury or infection $[43,172,175,200]$. AMPs also stimulate inflammatory and immune cell cytokine production, which in turn can modulate cellular functions [179, 201-204]. Additionally, hBD-3 has been shown to activate dendritic cells [174], raising the possibility that corneal/conjunctival epithelial hBD-3 may be able to activate epithelial Langerhans cells and stromal dendritic cells, which in turn may initiate an adaptive immune response.

In addition, some AMPs have been found to modulate angiogenesis/neovascularization. Interestingly, while LL37 appears to be pro-angiogenic [177], HNPs are reported to be anti-angiogenic $[205,206]$. As noted earlier, injury or insult to the ocular surface results in attraction of neutrophils. Thus, the relative levels of HNPs (from neutrophils) and LL-37 (from both neutrophils and epithelial cells) may influence the avascularity of the cornea after trauma.

Whilst there is still much work to be done to definitively define the roles of defensins, LL-37 and other multifunctional AMPs at the ocular surface, it is clear that the presence of these molecules is, as is the case with many other biological factors such as cytokines, a 'double-edged sword' in that they may have several beneficial functions, such as direct microbial killing, promotion of wound healing and modulation of immune responses, but this may come at the cost of unwanted inflammation and toxicity.

\section{AMPs as Ocular Surface Therapeutics}

AMPs show promise not only as novel antimicrobial agents capable of direct microbial killing, but, given the plethora of activities in which they appear capable of participating, they may, for example, find a place as immune modulators or mediators of wound healing. Antimicrobial properties such as broad-spectrum rapid killing ac- 
tivity and reduced likelihood of organisms developing resistance make AMPs a particularly attractive alternative to conventional antimicrobials. However, several factors have limited their development as therapeutic agents, including cost, susceptibility to proteases and cytotoxicity $[207,208]$. Strategies to circumvent these issues and hopefully accelerate the development process are now being developed, including using $\mathrm{D}$ rather than $\mathrm{L}$ amino acids to improve stability [209] and identifying the specific sequences in which the activity of interest (antimicrobial/ modulatory) resides so that shorter peptides can be used to reduce cost and minimize toxicity [210].

Several studies have addressed ways in which an AMPbased product may be used as an ocular surface therapeutic, including direct topical application to prevent and/or treat infections [211-213], incorporation into a contact lens [214] and as novel preservatives in contact lens solutions [215] and corneal storage media [216]. The results of in vivo studies into the efficacy of AMPs as stand-alone topical anti-infectives have been variable. Nos-Barbera et al. [211] showed that rabbits infected by intrastromal injection of $P$. aeruginosa then treated with synthetic peptides containing partial sequences from cecropin A (an insect AMP) and melittin (from bee venom) had reduced inflammatory signs and less damage than vehicle-treated controls. On the other hand, COL-1, a synthetic AMP with potent antimicrobial activity in vitro, had no clinical benefit in a rabbit model of $P$. aeruginosa keratitis [212]. In fact, peptide-treated animals had more signs of inflammation than control rabbits. Most recently, retrocyclin 2 , a synthetic $\theta$-defensin, was found to have antiviral activity in an in vivo murine model of herpes simplex-1 keratitis when given prophylactically; however, the peptide was not effective when administered for an active infection [213]. As noted earlier, tear film components are capable of inactivating some AMPs; indeed, this may have been responsible for the lack of COL-1 efficacy in vivo, and thus future studies aimed at developing a topical therapeutic AMP need to take this into consideration alongside issues such as potential cytotoxicity and unwanted inflammation. More encouraging results may be obtained by simultaneous application of more than one AMP to take advantage of synergistic interactions at low, non-cytotoxic concentrations. Additionally, novel delivery systems such as any of the several types of nanoparticles now available may help circumvent some of the problems associated with topical ocular administration.

Although a number of companies have undertaken the task, no AMP-based product has successfully been brought to market for any indication. However, there are a number in development $[207,208]$ for a variety of (mostly) infectious diseases and the next few years are likely to see the first of these appear on the market. An alternative approach to adding an AMP exogenously is to boost endogenous levels in the hope of achieving greater antimicrobial protection and/or modulation of cell function. That this is tenable for the ocular surface was recently shown in the aforementioned study by Kumar et al. [169], who found that prior application of the TLR 5 agonist flagellin upregulated CRAMP expression, reduced inflammation and improved outcome in a murine model of $P$. aeruginosa keratitis.

\section{Summary}

Current data show that the major AMPs at the ocular surface are $\alpha$ - and $\beta$-defensins and LL-37. Corneal and conjunctival epithelial cells are the source of $\beta$-defensins (hBD-1, -2 and -3) and LL-37, whereas neutrophils infiltrating the stroma in response to an inflammatory stimulus and in the tear film supply $\alpha$-defensins (HNP-1, -2 and -3 ) and additional LL-37. hBD- 1 and -3 and LL-37 are expressed in normal cornea and thus are likely to contribute to a baseline defence. hBD-3 and LL-37 have the most potent antimicrobial activity in vitro and are not as susceptible to physiological salt and other tear film components, so are the most likely to have independent activity at the ocular surface in vivo. In addition to affording protection by direct microbial killing, AMPs may also help to regulate activities such as corneal wound healing and immune responses. Owing to their broad-spectrum antimicrobial activity and multiple other actions, AMPs hold significant promise as therapeutic agents, and as a greater understanding of their regulation and biological roles is gained it is conceivable that an AMP-based product(s) may have a future place in the armamentarium of eye care professionals.

\section{Acknowledgements}

The author thanks Ms. Kimberly Thompson of the University of Houston College of Optometry Audio Visual services for drawing figure 1. The author's research on AMPs at the ocular surface is supported by grants from the National Institutes of Health (RO1 EY013175, EY007551 UHCO CORE grant) and the National Science Foundation (DMR-0706627) and a Norman Hackerman Advanced Research Program award (Texas Higher Education Coordinating Board). 


\section{References}

1 Ganz T: Defensins: antimicrobial peptides of innate immunity. Nat Rev Immunol 2003;3: 710-720.

-2 Tang YQ, Yuan J, Osapay G, Osapay K, Tran D, Miller CJ, Ouellette AJ, Selsted ME: A cyclic antimicrobial produced in primate leukocytes by the ligation of two truncated alpha-defensins. Science 1999;286:498-502.

-3 Leonova L, Kokryakov VN, Aleshina G, Hong T, Nguyen T, Zhao C, Waring AJ, Lehrer RL: Circular minidefensins and posttranslational generation of molecular diversity. J Leukoc Biol 2001;70:461-464.

$\checkmark 4$ Tran D, Tran PA, Tang YQ, Yuan J, Cole T, Selsted ME: Homodimeric theta-defensins from Rhesus macaque leukocytes: isolation, synthesis, antimicrobial activities, and bacterial binding properties of the cyclic peptides. J Biol Chem 2002;277:3079-3084.

$\checkmark 5$ Nguyen TX, Cole AM, Lehrer RI: Evolution of primate theta-defensins: a serpentine path to a sweet tooth. Peptides 2003;24:1647-1654.

-6 Ganz T, Selsted ME, Szklarek D, Harwig SS, Daher K, Bainton DF, Lehrer RI: Defensins. Natural peptide antibiotics of human neutrophils. J Clin Invest 1985;76:1427-1435.

7 Selsted ME, Harwig SS, Ganz T, Schilling JW, Lehrer RI: Primary structures of three human neutrophil defensins. J Clin Invest 1985;76:1436-1439.

$>8$ Wilde CG, Griffith JE, Marra MN, Snable JL, Scott RW: Purification and characterization of human neutrophil peptide-4, a novel member of the defensin family. J Biol Chem 1989;264:11200-11203.

$\checkmark 9$ Faurschou M, Sorensen OE, Johnsen AH, Askaa J, Borregaard N: Defensin-rich granules of human neutrophils: characterization of secretory properties. Biochim Biophys Acta 2002;1591:29-35.

10 Ganz T: Extracellular release of antimicrobial defensins by human polymorphonuclear leukocytes. Infect Immun 1987;55:568-571.

-11 Daher KA, Lehrer RI, Ganz T, Kronenberg $\mathrm{M}$ : Isolation and characterization of human defensin cDNA clones. Proc Natl Acad Sci USA 1988;85:7327-7331.

12 Valore EV, Ganz T: Posttranslational processing of defensins in immature human myeloid cells. Blood 1992;79:1538-1544.

13 Liu L, Ganz T: The pro region of human neutrophil defensin contains a motif that is essential for normal subcellular sorting. Blood 1995;85:1095-1103.

- 14 Valore EV, Martin E, Harwig SS, Ganz T: Intramolecular inhibition of human defensin HNP-1 by its propiece. J Clin Invest 1996;97: 1624-1629.

15 Wu Z, Li X, Ericksen B, de Leeuw E, Zou G, Zeng P, Xie C, Li C, Lubkowski J, Lu WY, Lu $\mathrm{W}$ : Impact of pro segments on the folding and function of human neutrophil alpha-defensins. J Mol Biol 2007;368:537-549.
16 Agerbeth B, Charo J, Werr J, Olsson B, Idali F, Lindbom L, Kiessling R, Jornvall H, Wigzell H, Gudmundsson GH: The human antimicrobial and chemotactic peptides LL-37 and alpha-defensins are expressed by specific lymphocyte and monocyte populations. Blood 2000;96:3086-3093.

17 Rodriguez-Garcia M, Oliva H, Climent N, Garcia F, Gatell JM, Gallart T: Human immature monocyte-derived dendritic cells produce and secrete alpha defensins $1-3$. J Leukoc Biol 2007;82:1143-1146.

-18 Tan BH, Meinken C, Bastian M, Bruns H, Legaspi A, Ochoa MT, Krutzik SR, Bloom BR, Ganz T, Modlin RL, Stenger S: Macrophages acquire neutrophil granules for antimicrobial activity against intracellular pathogens. J Immunol 2006;177:1864-1871.

19 Jones DE, Bevins CL: Paneth cells of the human small intestine express an antimicrobial peptide gene. J Biol Chem 1992;267: 23216-23225.

20 Jones DE, Bevins CL: Defensin- 6 mRNA in human Paneth cells: implications for antimicrobial peptides in host defense of the human bowel. FEBS Lett 1993;315:187-192.

21 Quayle AJ, Porter EM, Nussbaum AA, Wang YM, Brabec C, Yip KP, Mok SC: Gene expression, immunolocalization and secretion of human defensin-5 in human female reproductive tract. Am J Pathol 1998;152:12471258.

-22 Frye M, Bargon J, Dauletbaev N, Weber A, Wagner TO, Gropp R: Expression of human alpha-defensin 5 (HD5) mRNA in nasal and bronchial epithelial cells. J Clin Pathol 2000; 53:770-773.

23 Ghosh D, Porter E, Shen B, Lee SK, Wilk D, Drazba J, Yadav SP, Crabb JW, Ganz T, Bevins CL: Paneth cell trypsin is the processing enzyme for human defensin-5. Nat Immunol 2002;3:583-590.

24 Linzmeier R, Ho CH, Hoang BV, Ganz T: A $450-\mathrm{kb}$ contig of defensin genes on human chromosome 8p23. Gene 1999;233:205-211.

25 Linzmeier R, Michaelson D, Liu L, Ganz T: The structure of neutrophil defensin genes. FEBS Lett 1993;321:267-273.

26 Mallow EB, Harris A, Salzman N, Russell JP, DeBerardinis RJ, Ruchelli E, Bevins CL: Human enteric defensins. Gene structure and developmental expression. J Biol Chem 1996; 271:4038-4045.

-27 Mars WM, Patmasiriwat P, Maity T, Huff V, Weil MM, Saunders GF: Inheritance of unequal numbers of the genes encoding the human neutrophil defensins HP-1 and HP-3. J Biol Chem 1995;270:30371-30376.

28 Aldred PMR, Hollox EJ, Armour JAL: Copy number polymorphism and expression level variation of the human $\alpha$-defensin genes DEFA1 and DEFA3. Hum Mol Genet 2005; 14:2045-2052.
-29 Linzmeier RM, Ganz T: Human defensin gene copy number polymorphisms: comprehensive analysis of independent variation in $\alpha$ - and $\beta$-defensin regions at 8p22-p23. Genomics 2005;86:423-430.

30 Ballana E, Gonzalez JR, Bosch N, Estivill X: Inter-population variability of DEFA3 gene absence: correlation with haplotype structure and population variability. BMC Genomics 2007;8:14.

31 Duits LA, Ravensbergen B, Rademaker M, Hiemstra PS, Nibbering PH: Expression of beta-defensin 1 and 2 mRNA by human monocytes, macrophages and dendritic cells. Immunology 2002;106:517-525.

32 Ryan LK, Diamond G, Amrute S, Feng Z, Weinberg A, Fitzgerald-Bocarsly P: Detection of HBD1 peptide in peripheral blood mononuclear cell subpopulations by intracellular flow cytometry. Peptides 2003;24: 1785-1794.

>33 Bensch KW, Raida M, Magert HJ, SchulzKnappe P, Forssmann WG: hBD-1: a novel beta-defensin from human plasma. FEBS Lett 1995;368:331-335.

34 McCray PB, Bentley L: Human airway epithelia express a beta-defensin. Am J Respir Cell Mol Biol 1997;16:343-349.

35 Valore EV, Park CH, Quayle AJ, Wiles KR, McCray PB, Ganz T: Human beta-defensin1: an antimicrobial peptide of urogenital tissues. J Clin Invest 1998;101:1633-1642.

36 Paulsen FP, Pufe T, Schaudig U, Held-Feindt J, Lehmann J, Schroder JM, Tillmann BN: Detection of natural peptide antibiotics in human nasolacrimal ducts. Invest Ophthalmol Vis Sci 2001;42:2157-2163.

37 Jia HP, Starner T, Ackermann M, Kirby P, Tack BF, McCray PB: Abundant human betadefensin-1 expression in milk and mammary gland epithelium. J Pediatr 2001;38:109112.

38 Harder J, Bartels J, Christophers E, Schroder JM: A peptide antibiotic from human skin. Nature 1997;387:861.

39 O’Neil DA, Porter EM, Elewaut D: Expression and regulation of the human beta-defensins hBD-1 and hBD-2 in intestinal epithelium. J Immunol 1999; 163:6718-6724.

40 Wada A, Ogushi K, Kimura T, Hojo H, Mori N, Suzuki S, Kumatori A, Se M, Nakahara Y, Nakamura M, Moss J, Hirayama T: Helicobacter pylori-mediated transcriptional regulation of the human beta-defensin-2 gene requires NF-кB. Cell Microbiol 2001;3:115123.

41 Wang X, Zhang Z, Louboutin JP, Moser C, Weiner DJ, Wilson JM: Airway epithelia regulate expression of human beta-defensin-2 through Toll-like receptor 2. FASEB J 2003; 17:1727-1729. 
-42 Harder J, Bartels J, Christophers E, Schröder JM: Isolation and characterization of human-beta-defensin-3, a novel inducible peptide antibiotic. J Biol Chem 2001;276:57075713.

-43 Garcia JR, Jaumann F, Schulz S, Krause A, Rodriguez-Jimenez J, Forssmann U, Adermann K, Kluver E, Vogelmeier C, Becker D, Hedrich R, Forssmann WG, Bals R: Identification of a novel, multifunctional beta-defensin (human beta-defensin 3) with specific antimicrobial activity. Its interaction with plasma membranes of Xenopus oocytes and the induction of macrophage chemoattraction. Cell Tissue Res 2001;306:257-264.

-44 Garcia JR, Krause A, Schulz S, RodriguezJimenez J, Kluver E, Adermann K, Forssmann U, Frimpong-Boateng A, Bals R, Forssmann WG: Human beta-defensin 4: a novel inducible peptide with a salt-sensitive spectrum of antimicrobial activity. FASEB J 2001;15:1819-1821.

-45 Yamaguchi Y, Nagase T, Makita R, Fukuhara S, Tomita T, Tominaga T, Kurihara H, Ouchi Y: Identification of multiple novel epididymis specific beta-defensin isoforms in humans and mice. J Immunol 2002;169:25162523.

-46 Liu L, Wang L, Jia HP, Zhao C, Heng HH, Schutte BC, McCray PB Jr, Ganz T: Structure and mapping of the human beta-defensin HBD-2 gene and its expression at sites of inflammation. Gene 1998;222:237-244.

-47 Diamond G, Kaiser V, Rhodes J, Russel JP, Bevins CL: Transcriptional regulation of beta-defensin gene expression in tracheal epithelial cells. Infect Immun 2000;68:113119.

-48 Harder J, Meyer-Hoffert U, Teran LM, Schwichtenberg L, Bartels J, Maune S, Schröder JM: Mucoid Pseudomonas aeruginosa, TNF alpha, and IL-beta, but not IL-6, induce human beta-defensin-2 in respiratory epithelia. Am J Respir Cell Mol Biol 2000; 22:714-721.

49 Liu L, Zhao C, Heng HH, Ganz T: The human beta-defensins-1 and alpha defensins are encoded by adjacent genes: two peptide families with differing disulfide topology share a common ancestry. Genomics 1997; 43:316-320.

-50 Schutte BC, Mitros JP, Bartlett JA, Walters JD, Jia HP, Welsh MJ, Casavant TL, McCray PB Jr: Discovery of five conserved beta-defensin gene clusters using a computational search strategy. Proc Natl Acad Sci USA 2002;99:2129-2133.

51 Patil AA, Cai Y, Sang Y, Blecha F, Zhang G: Cross-species analysis of the mammalian beta-defensin gene family: presence of syntenic gene clusters and preferential expression in the male reproductive tract. Physiol Genomics 2005;23:5-17.
52 Rodriguez-Jimenez FJ, Krause A, Schultz S, Forssmann WG, Conejo-Garcia JR, Schreeb R, Motzkus D: Distribution of new human beta-defensin genes clustered on chromosome 20 in functionally different segments of epididymis. Genomics 2003;81:175-183.

53 Yenugu S, Hamil KG, Radhakrishnan Y, French FS, Hall SH: The androgen-regulated epididymal sperm-binding protein, human beta-defensin 118 (DEFB118) (formerly ESC42), is an antimicrobial beta-defensin. Endocrinology 2004;145:3165-3173.

54 Premratanachai P, Joly S, Johnson SK, McCray PB, Jia HP, Guthmiller JM: Expression and regulation of novel human beta-defensins in gingival keratinocytes. Oral Microbiol Immunol 2004;19:111-117.

55 Kao CY, Chen Y, Zhao YH, Wu R: ORFeomebased search of airway epithelial cell-specific novel human beta-defensin genes. Am J Respir Cell Mol Biol 2003;29:71-80.

56 Hollox EJ, Armour JAL, Barber JCK: Extensive normal copy number variation of a $\beta$ defensin antimicrobial-gene cluster. Am J Hum Genet 2003;73:591-600.

57 Matsushita I, Hasegawa K, Nakata K, Yasuda $\mathrm{K}$, Tokinaga K, Keicho N: Genetic variants of human beta-defensin-1 and chronic obstructive pulmonary disease. Biochem Biophys Res Commun 2002;291:17-22.

58 Levy H, Raby BA, Lake S, Tantisira KG, Kwiatkowski D, Lazarus R, Silverman EK, Richter B, Klimecki WT, Vercelli D, Martinez FD, Weiss ST: Association of defensin beta-1 gene polymorphisms with asthma. J Allergy Clin Immunol 2005;115:252-258.

59 Donald CD, Sun CQ, Lim SD, Macosaka J, Cohen C, Amin MB, Yound AN, Ganz TA, Marshall FF, Petros JA: Cancer specific loss of $\beta$-defensin 1 in renal and prostatic carcinomas. Lab Invest 2003;83:501-505.

60 Carter J, Churchill AJ, Gorman C, Haynes R: A case of bilateral endophthalmitis and carriage of beta-defensin 144CC genotype. $\mathrm{Br} \mathrm{J}$ Ophthalmol 2007;91:1249-1250.

61 Zanetti M, Gennaro R, Romeo D: Cathelicidins: a novel protein family with a common proregion and a variable $\mathrm{C}$-terminal antimicrobial domain. FEBS Lett 1995;374:1-5.

62 Ritonja A, Kopitar M, Jerala R, Turk V: Primary structure of a new cysteine proteinase inhibitor from pig leukocytes. FEBS Lett 1989;255:211-214

63 Agerberth B, Gunne H, Odeberg J, Kogner P, Boman HG, Gudmundsson GH: FALL-39, a putative human peptide antibiotic, is cysteine-free and expressed in bone marrow and testis. Proc Natl Acad Sci USA 1995;92:195199.

64 Cowland J, Johnsen A, Borregaard N: hCAP18 , a cathelin/pro-bactenecin-like protein of human neutrophil specific granules. FEBS Lett 1995;368:173-176.

-65 Larrick J, Hirata M, Balint R, Lee J, Zhong J, Wright SC: Human CAP 18: a novel antimicrobial lipopolysaccharide-binding protein. Infect Immun 1995;63:1291-1297.
66 Gudmundsson GH, Agerberth B, Odeberg J, Bergman T, Olsson B, Salcedo R: The human gene FALL39 and processing of the cathelin precursor to the antibacterial peptide LL-37 in granulocytes. Eur J Biochem 1996;238: 325-332.

67 Linzmeier RM, Ganz T: Copy number polymorphisms are not a common feature of innate immune genes. Genomics 2006;88:122126.

68 Bals R, Wilson JM: Cathelicidins - a family of multifunctional antimicrobial peptides. Cell Mol Life Sci 2003;60:711-720.

69 Larrick JW, Morgan JG, Palings I, Hirata M, Yen MH: Complementary DNA sequence of rabbit CAP18 - a unique lipopolysaccharide binding protein. Biochem Biophys Res Commun 1991;179:170-175.

70 Sorensen OE, Follin P, Johnsen AH, Calafat J, Tjabringa GS, Hiemstra PS, Borregaard N: Human cathelicidin, hCAP18, is processed to the antimicrobial peptide LL-37 by extracellular cleavage with proteinase 3 . Blood 2001;97:3951-3959.

71 Di Nardo A, Vitiello A, Gallo RL: Mast cell antimicrobial activity is mediated by expression of cathelicidin antimicrobial peptide. J Immunol 2003;170:2274-2278.

72 Bals R, Wang X, Zasloff M, Wilson JM: The peptide antibiotic LL-37/hCAP18 is expressed in epithelia of the human lung where it has broad spectrum antimicrobial activity at the airway surface. Proc Natl Acad Sci USA 1998;95:9541-9546.

73 Frohm M, Agerberth B, Ahangari G, StahleBackdahl M, Liden S, Wigzell H, Gudmundsson GH: The expression of the gene coding for the antibacterial peptide LL-37 is induced in human keratinocytes during inflammatory disorders. J Biol Chem 1997;272:1525815263.

-74 Frohm-Nilsson M, Sandstedt B, Sorensen O, Weber G, Borregaard N, Stahle-Backdahl M: The human cationic antimicrobial protein (hCAP18), a peptide antibiotic, is widely expressed in human squamous epithelia and colocalizes with interleukin-6. Infect Immun 1999;67:2561-2566.

75 Murakami M, Ohtake R, Dorschner B, Schittek B, Garbe C, Gallo RL: Cathelicidin antimicrobial peptide expression in sweat, an innate defence system for the skin. J Invest Dermatol 2002;119:1090-1095.

76 Wang TT, Nestel FP, Bourdeau V, Nagai Y, Wang Q, Liao J, Tavera-Mendoza L, Lin R, Hanrahan JW, Mader S, White JH: Cutting edge: 1,25 -dihydroxyvitamin $\mathrm{D}_{3}$ is a direct inducer of antimicrobial peptide gene expression. J Immunol 2004;173:2909-2912.

77 Ooi EH, Wormald PJ, Carney AS, James CL, Tan LW: Fungal allergens induce cathelicidin LL-37 expression in chronic rhinosinusitis patients in a nasal explant model. Am J Rhinol 2007;21:367-372. 
78 Li Q, Kumar A, Gui JF, Yu FS: Staphylococcus aureus lipoproteins trigger human corneal epithelial innate response through toll-like receptor-2. Microb Pathog 2008;44:426434.

79 Zaiou M, Nizet V, Gallo RL: Antimicrobial and protease inhibitory functions of the human cathelicidin (hCAP18/LL-37) prosequence. J Invest Dermatol 2003;120:810816.

80 Murakami M, Lopez-Garcia B, Braff M, Dorschner RA, Gallo RL: Postsecretory processing generates multiple cathelicidins for enhanced topical antimicrobial defense. J Immunol 2004;172:3070-3077.

-81 Yamasaki K, Schauber J, Coda A, Lin H, Dorschner RA, Schecter NM, Bonnart C, Descargues P, Hovnanian A, Gallo RL: Kallikrein-mediated proteolysis regulates the antimicrobial effects of cathelicidins in skin. FASEB J 2006;20:2068-2080.

82 Krause A, Neitz S, Magert HJ, Schulz A, Forssmann WG, Schulz-Knappe P, Adermann K: LEAP-1, a novel highly disulfidebonded human peptide, exhibits antimicrobial activity. FEBS Lett 2000;480:147-150.

83 Park CH, Valore EV, Waring AJ, Ganz T: Hepcidin, a urinary antimicrobial peptide synthesized in the liver. J Biol Chem 2001; 276:7806-7810.

$>84$ Krause A, Sillard R, Kleemeier B, Kluver E, Maronde E, Conejo-Garcia JR, Forssmann WG, Schulz-Knappe P, Nehls MC, Wattler F, Wattler S, Adermann K: Isolation and biochemical characterization of LEAP-2, a novel blood peptide expressed in the liver. Protein Sci 2003;12:143-152.

-85 Ganz T: Hepcidin - a peptide hormone at the interface of innate immunity and iron metabolism. Curr Top Microbiol Immunol 2006;306:183-198.

-86 Schittek B, Hipfel R, Sauer B, Bauer J, Kalbacher H, Stevanovic S, Schirle M, Schroder K, Blin N, Meier F, Rassner G, Garbe C: Dermcidin: a novel antibiotic peptide secreted by sweat glands. Nat Immunol 2001;2: 1133-1137.

87 Kavanagh K, Dowd S: Histatins: antimicrobial peptides with therapeutic potential. J Pharm Pharmacol 2004;56:285-289.

88 Tang YQ, Yeaman MR, Selsted ME: Antimicrobial peptides from human platelets. Infect Immun 2002;277:37647-37654.

-89 Cole AM, Ganz T, Liese AM, Burdick MD, Liu L, Strieter RM: Cutting edge: IFN-inducible ELR-CXC chemokines display defensinlike antimicrobial activity. J Immunol 2001; 167:623-627.

-90 Yang D, Chen Q, Hoover DM, Staley P, Tucker KD, Lubkowski J, Oppenheim JJ: Many chemokines including CCL20/MIP-3alpha display antimicrobial activity. J Leukoc Biol 2003;74:448-455.

-91 Radek K, Gallo RL: Antimicrobial peptides: natural effectors of the innate immune system. Semin Immunopathol 2007;29:27-43.
\$92 Gottsch JD, Li Q, Ashraf MF, O’Brien TP, Stark WJ, Liu SH: Defensin gene expression in the cornea. Curr Eye Res 1998;17:10821086.

93 Haynes RJ, Tighe PJ, Dua HS: Innate defence of the eye by antimicrobial defensin peptides. Lancet 1998;352:451-452.

-94 Haynes RJ, Tighe PJ, Dua HS: Antimicrobial defensin peptides of the human ocular surface. Br J Ophthalmol 1999;83:737-741.

$\checkmark 95$ Zhou L, Huang LQ, Beuerman RW, Grigg ME, Li SF, Chew FT, Ang L, Stern ME, Tan D: Proteomic analysis of human tears: defensin expression after ocular surface surgery. J Proteome Res 2004;3:410-416.

$\checkmark 96$ Hida RY, Ohashi Y, Takano Y, Dogru M, Goto E, Fujishima H, Saito I, Saito K, Fukase Y, Tsubota K: Elevated levels of human alpha-defensin in tears of patients with allergic conjunctival disease complicated by corneal lesions: detection by SELDI ProteinChip system and quantification. Curr Eye Res 2005;30:723-730.

$\$ 97$ Hattenbach LO, Gumbel H, Kippenberger $\mathrm{S}$ : Identification of beta-defensins in human conjunctiva. Antimicrob Agents Chemother 1998;42:3332.

-98 McNamara NA, Van R, Tuchin OS, Fleiszig SMJ: Ocular surface epithelia express mRNA for human beta defensin-2. Exp Eye Res 1999;69:483-490.

$\checkmark 99$ Lehmann OJ, Hussain IR, Watt PJ: Investigation of $\beta$-defensin gene expression in the ocular anterior segment by semiquantitative RT-PCR. Br J Ophthalmol 2000;84: 523-526.

100 McDermott AM, Redfern RL, Zhang B, Pei Y, Huang L, Proske RJ: Defensin expression by the cornea: multiple signaling pathways mediate IL-1beta stimulation of hBD-2 expression by corneal epithelial cells. Invest Ophthalmol Vis Sci 2003;44:1859-1865.

101 Narayanan S, Miller WL, McDermott AM: Expression of human $\beta$-defensins in conjunctival epithelium: relevance to dry eye disease. Invest Ophthalmol Vis Sci 2003;44: 3795-3801

102 Kumar A, Yin J, Zhang J, Yu FSX: Modulation of corneal epithelial innate immune response to Pseudomonas infection by flagellin pretreatment. Invest Ophthalmol Vis Sci 2007;48:4664-4670.

103 Kumar A, Zhang J, Yu FS: Innate immune response of corneal epithelial cells to Staphylococcus aureus infections: role of peptidoglycan in stimulating proinflammatory cytokine secretion. Invest Ophthalmol Vis Sci 2004;45:3513-3522.

104 Kumar A, Zhang J, Yu FS: Toll-like receptor 2-mediated expression of beta-defensin-2 in human corneal epithelial cells. Microbes Infect 2006;8:380-389.

- 105 Shin JS, Kim CW, Kwon YS, Kim JC: Human beta-defensin 2 is induced by interleukin-1 beta in the corneal epithelial cells. Exp Mol Med 2004;36:204-210.
106 McDermott AM, Redfern RL, Zhang B: Human $\beta$-defensin 2 is up-regulated during re-epithelialization of the cornea. Curr Eye Res 2001;22:64-67.

107 Kawasaki S, Kawamoto S, Yokoi N, Connon C, Minesaki Y, Kinoshita S, Okubo K: Upregulated gene expression in the conjunctival epithelium of patients with Sjögren's syndrome. Exp Eye Res 2003;77:17-26.

108 McIntosh RS, Cade JE, Al-Abed M, Shanmuganathan V, Gupta R, Bhan A, Tighe PJ, Dua HS: The spectrum of antimicrobial peptide expression at the ocular surface. Invest Ophthalmol Vis Sci 2005;46:13791385.

109 Nomura I, Goleva E, Howell MD, Hamid QA, Ong PY, Hall CF, Darst MA, Gao B, Boguniewicz M, Travers JB, Leung DY: Cytokine milieu of atopic dermatitis, as compared to psoriasis, skin prevents induction of innate immune response genes. J Immunol 2003; 171:3262-3269.

110 Huang LC, Jean D, Proske RJ, Reins RY, McDermott AM: Ocular surface expression and in vitro activity of antimicrobial peptides. Curr Eye Res 2007;32:595-609.

$\checkmark 111$ Abedin A, Mohammed I, Hopkinson A, Dua HS: A novel antimicrobial peptide on the ocular surface shows decreased expression in inflammation and infection. Invest Ophthalmol Vis Sci 2008;49:28-33.

-112 Huang LC, Redfern RL, Narayanan S, Reins RY, McDermott AM: In vitro activity of human beta-defensin 2 against Pseudomonas aeruginosa in the presence of tear fluid. Antimicrob Agents Chemother 2007;51:38533860 .

113 Gordon YJ, Huang LC, Romanowski EG, Yates KA, Proske RJ, McDermott AM: Human cathelicidin (LL-37), a multifunctional peptide, is expressed by ocular surface epithelia and has potent antibacterial and antiviral activity. Curr Eye Res 2005;30:110.

114 Huang LC, Petkova TD, Reins RY, Proske RJ, McDermott AM: Multifunctional roles of human cathelicidin (LL-37) at the ocular surface. Invest Ophthalmol Vis Sci 2006;47: 2369-2380.

115 Martins SA, Castro-Combs J, Camacho W, Wittmann P, Hicks JL, De Marzo AM, Eberhart CG, Behrens A: Dermcidin expression in the eye - potential protective mechanisms against ocular bacterial invasion. Invest Ophthalmol Vis Sci 2008;49: ARVO E-abstract 836.

116 Steele PS, Jumblatt MM: Defense proteins of the ocular surface. Invest Ophthalmol Vis Sci 2004;45:ARVO E-abstract 3792.

-117 Spandau UH, Toksoy A, Verhaart S, Gillitzer R, Kruse FE: High expression of chemokines Gro-alpha (CXCL-1), IL-8 (CXCL8), and MCP-1 (CCL-2) in inflamed human corneas in vivo. Arch Ophthalmol 2003; 121:825-831. 
118 Steele PS, Jumblatt MM, Smith NB, Pierce WM: Detection of histatin 5 in normal human schirmer strip samples by mass spectroscopy. Invest Ophthalmol Vis Sci 2002; 43:ARVO E-abstract 98.

-119 Stoeckelhuber M, Messmer EM, Schubert C, Stoeckelhuber BM, Koehler C, Welsch U, Bals R: Immunolocalization of defensins and cathelicidin in human glands of Moll. Ann Anat 2008;190:230-237.

-120 Schibli DJ, Hunter HN, Aseyev B, Starner TD, Wieneck JM, McCray PB Jr, Tack BF, Vogel HJ: The solution structures of the human beta-defensins lead to a better understanding of the potent bactericidal activity of hBD-3 against Staphylococcus aureus. J Biol Chem 2002;277:8279-8289.

-121 Dorschner RA, Lopez-Garcia B, Peschel A, Krause D, Morikawa K, Nizet V, Gallo RL: The mammalian ionic environment dictates microbial susceptibility to antimicrobial defense peptides. FASEB J 2006;20:3542.

122 Matsuzaki K, Sugishita K, Fujii N, Miyajima K: Molecular basis for membrane selectivity of an antimicrobial peptide, magainin 2. Biochemistry 1995;34:3423-3429.

- 123 Tytler EM, Anantharamaiah GM, Walker DE, Mishra VK, Palgunachari MN, Segrest JP: Molecular basis for prokaryotic specificity of magainin-induced lysis. Biochemistry 1995;34:4393-4401.

124 Shai Y: Mode of action of membrane active antimicrobial peptides. Biopolymers 2002; 66:236-248.

-125 van't Hof W, Veerman ECI, Helmerhorst EJ, Amerongen AV: Antimicrobial peptides: properties and applicability. Biol Chem 2001;382:597-619.

- 126 Matsuzaki K, Murase O, Fujii N, Miyajima $\mathrm{K}$ : An antimicrobial peptide, magainin 2, induced rapid flip-flop of phospholipids coupled with pore formation and peptide translocation. Biochemistry 1996;35: 11361-11368.

- 127 Yang L, Harroun TA, Weiss TM, Ding L, Huang HW: Barrel-stave model or toroidal model? A case study on melittin pores. Biophys J 2001;81:1475-1485.

128 Bechinger B, Lohner K: Detergent-like actions of linear amphipathic cationic antimicrobial peptides. Biochim Biophys Acta 2006;1758:1529-1539.

129 Pkorny A, Almeida PFF: Kinetics of dye efflux and lipid flip-flop induced by delta-lysin in phosphatidylcholine vesicle and the mechanism of graded release by amphipathic, alpha-helical peptides. Biochemistry 2004;43:8846-8857.

-130 Miteva M, Anderson M, Karshikoff A, Otting G: Molecular electroporation: a unifying concept for the description of membrane pore formation by antibacterial peptides, exemplified with NK-lysin. FEBS Lett 1999;462:155-158.
131 Lehrer RI, Barton A, Daher KA, Harwig SS, Ganz T, Selsted ME: Interaction of human defensins with Escherichia coli. Mechanism of bactericidal activity. J Clin Invest 1989; 84:553-561.

132 Skerlavaj B, Romeo D, Gennaro R: Rapid membrane permeabilization and inhibition of vital functions of gram-negative bacteria by bactenecins. Infect Immun 1990;58:3724-3730.

133 Boman HG, Agerberth B, Boman A: Mechanism of action on Escherichia coli of cecropin Pa and PR-39, two antibacterial peptides from pig intestine. Infect Immun 1993;62:2978-2984.

134 Brotz H, Bierbaum G, Leopold K, Reynolds PE, Sahl HG: The lantibiotic mersacidin inhibits peptidoglycan synthesis by targeting lipid II. Antimicrob Agents Chemother 1998;42:154-160.

135 Subbalakshmi C, Sitaram N: Mechanism of antimicrobial action of indolicidin. FEMS Microbiol Lett 1998;160:91-96.

136 Oh J, Cajal Y, Skowronska EM, Belkin S, Chen J, Van Dyk TK, Sasser M, Jain MK: Cationic peptide antimicrobials induce selective transcription of micF and osmY in Escherichia coli. Biochim Biophys Acta 2000;1463:43-54.

137 Otvos L Jr, O I, Rogers ME, Consolvo PJ, Condie BA, Lovas S, Bulet P, BlaszczykThurin M: Interaction between heat shock proteins and antimicrobial peptides. Biochemistry 2000;39:14150-14159.

138 Kragol G, Lovas S, Varadi G, Condie BA, Hoffmann R, Otvos L: The antibacterial peptide pyrrhocoricin inhibits the ATPase actions of DnaK and prevents chaperoneassisted protein folding. Biochemistry 2001; 40:3016-3026.

139 Patrzykat A, Friedrich CL, Zhang L, Mendoza V, Hancock RE: Sublethal concentrations of pleurocidin-derived antimicrobial peptides inhibit macromolecular synthesis in Escherichia coli. Antimicrob Agents Chemother 2002;46:605-614.

140 Brogden KA: Antimicrobial peptides: pore formers or metabolic inhibitors in bacteria? Nat Rev Microbiol 2005;3:238-250.

141 Hale JD, Hancock RE: Alternative mechanisms of action of cationic antimicrobial peptides on bacteria. Expert Rev Anti Infect Ther 2007;5:951-959.

142 Wimley WC, Selsted ME, White SH: Interactions between human defensins and lipid bilayers: evidence for formation of multimeric pores. Protein Sci 1994;3:1362-1373.

143 Hoover DM, Rajashankar KR, Blumenthal R, Puri A, Oppenheim JJ, Chertov O, Lubkowski J: The structure of human beta-defensin-2 shows evidence of higher order oligomerization. J Biol Chem 2000;275: 32911-32918.
144 Wu Z, Hoover DM, Yang D, Boulegue C, Santamaria F, Oppenheim JJ, Lubkowski J, $\mathrm{Lu} \mathrm{W}$ : Engineering disulfide bridges to dissect antimicrobial and chemotactic activities of human beta-defensin-3. Proc Natl Acad Sci USA 2003;100:8880-8885.

145 Kluver E, Schulz-Maronde S, Scheid S, Meyer B, Forssmann WG, Adermann K: Structure-activity relation of human betadefensin 3: influence of disulfide bonds and cysteine substitution on antimicrobial activity and cytotoxicity. Biochemistry 2005; 44:9804-9816.

146 Hoover DM, Wu Z, Tucker K, Lu W, Lubkowski J: Antimicrobial characterization of human $\beta$-defensin 3 derivatives. Antimicrob Agents Chemother 2003;47:2804-2809.

147 Johansson J, Gudmundsson GH, Rottenberg ME, Berndt KD, Agerberth B: Conformation-dependent antibacterial activity of the naturally occurring human peptide LL37. J Biol Chem 1998;273:3718-3724.

- 148 Oren Z, Lerman JC, Gudmundsson GH, Agerberth B, Shai Y: Structure and organization of the human antimicrobial peptide LL-37 in phospholipids membranes: relevance to the molecular basis for its noncell-selective activity. Biochem J 1999;341: 501-513.

149 Durr UHN, Sudheendra US, Ramamoorthy A: LL-37, the only human member of the cathelicidin family of antimicrobial peptides. Biochim Biophys Acta 2006;1578: 1408-1425.

150 Henzler Wildman KA, Lee DK, Ramamoorthy A: Mechanism of lipid bilayer disruption by the human antimicrobial peptide LL-37. Biochemistry 2003;42: 6545-6558

151 Neville F, Cahuzac M, Konovalov O, Ishitsuka Y, Lee KY, Kuzmenko I, Kale GM, Gidalevitz D: Lipid headgroup discrimination by antimicrobial peptide LL-37: insight into mechanism of action. Biophys J 2006; 90:1275-1287.

152 Sevcsik E, Pabst G, Jilek A, Lohner K: How lipids influence the mode of action of membrane active peptides. Biochim Biophys Acta 2007;1768:2586-2595.

153 Li X, Li Y, Han H, Miller DW, Wang G: Solution structures of human LL-37 fragments and NMR-based identification of a minimal membrane-targeting antimicrobial and anticancer region. J Am Chem Soc 2006;128:5776-5785.

-154 Feng Z, Jiang B, Chandra J, Ghannoum M, Nelson S, Weinberg A: Human beta-defensins: differential activity against Candidal species and regulation by Candida albicans. J Dent Res 2005;84:445-450.

155 den Hertog AL, van Marle J, van Veen HA, Van't Hof W, Bolscher JG, Veerman EC, Nieuw Amerongen AV: Candidacidal effects of two antimicrobial peptides: histatin 5 causes small membrane defects, but LL-37 causes massive disruption of the cell membrane. Biochem J 2005;388:689-695. 
156 Lopez-Garcia B, Lee PH, Yamasaki K, Gallo RL: Anti-fungal activity of cathelicidins and their potential role in Candida albicans skin infection. J Invest Dermatol 2005;125: 108-115.

-157 Daher KA, Selsted ME, Lehrer RI: Direct inactivation of viruses by human granulocyte defensins. J Virol 1986;60:1068-1074.

-158 Bastian A, Schafer H: Human alpha-defensin-1 (HNP-1) inhibits adenoviral infection in vitro. Regul Pept 2001;101:157-161.

-159 Zhang L, Yu W, He T, Yu J, Caffrey RE, Dalmasso EA, Fu S, Pham T, Mei J, Ho JJ, Zhang W, Lopez P, Ho DD: Contribution of human alpha-defensins 1,2 , and 3 to the antiHIV-1 activity of CD8 antiviral factor. Science 2002;298:995-1000.

160 Shai Y, Makovitzky A, Avrahami D: Host defense peptides and lipopeptides: modes of action and potential candidates for the treatment of bacterial and fungal infections. Curr Protein Pept Sci 2006;7:479486.

-161 Klotman ME, Chang TL: Defensins in innate antiviral immunity. Nat Rev Immunol 2006;6:447-456.

162 Oren A, Ganz T, Liu L, Meerloo T: In human epidermis, $\beta$-defensin 2 is packaged in lamellar bodies. Exp Mol Pathol 2003;74: 180-182.

-163 Braff MH, Di Nardo A, Gallo RL: Keratinocytes store the antimicrobial peptide cathelicidin in lamellar bodies. J Invest Dermatol 2005; 124:394-400.

-164 Singh PK, Tack BF, McCray PB Jr, Welsh MJ: Synergistic and additive killing by antimicrobial factors found in human airway surface liquid. Am J Physiol Lung Cell Mol Physiol 2000;279:L799-L805.

- 165 Nagaoka I, Hirota S, Yomogida S, Ohwada A, Hirata M: Synergistic actions of antibacterial neutrophil defensins and cathelicidins. Inflamm Res 2000;49:73-79.

-166 Chen X, Niyonsaba F, Ushio H, Okuda D, Nagaoka I, Ikeda S, Okumura K, Ogawa H: Synergistic effect of antibacterial agents human beta-defensins, cathelicidin LL-37 and lysozyme against Staphylococcus aureus and Escherichia coli. J Dermatol Sci 2005; 40:123-132.

-167 Huang LC, Reins RY, Gallo RL, McDermott AM: Cathelicidin-deficient (Cnlp-/-) mice show increased susceptibility to Pseudomonas aeruginosa keratitis. Invest Ophthalmol Vis Sci 2007;48:4498-4508.

- 168 Huang X, Du W, McClellen SA, Barrett RP, Hazlett LD: TLR4 is required for host resistance in Pseudomonas aeruginosa keratitis. Invest Ophthalmol Vis Sci 2006;47:49104916.

-169 Kumar A, Hazlett LD, Yu FS: Flagellin suppresses the inflammatory response and enhances bacterial clearance in a murine model of Pseudomonas aeruginosa keratitis. Infect Immun 2008;76:89-96.
170 Khine AA, Del Sorbo L, Vaschetto R, Voglis S, Tullis E, Slutsky AS, Downey GP, Zhang $\mathrm{H}$ : Human neutrophil peptides induce interleukin-8 production through the P2Y6 signaling pathway. Blood 2006;107:29362942.

171 Syeda F, Liu HY, Tullis E, Liu M, Slutsky AS, Zhang $\mathrm{H}$ : Differential signaling mechanisms of HNP-induced IL-8 production in human lung epithelial cells and monocytes. J Cell Physiol 2008;214:820-827.

172 Yang D, Chertov O, Bykovskaia SN, Chen Q, Buffo MJ, Shogan J, Anderson M, Schröder JM, Wang JM, Howard OM, Oppenheim JJ: Beta-defensins: linking innate and adaptive immunity through dendritic and $\mathrm{T}$ cell CCR6. Science 1999;286:525-528.

173 Niyonsaba F, Ogawa H, Nagaoka I: Human beta-defensin-2 functions as a chemotactic agent for tumour necrosis factor-alphatreated human neutrophils. Immunology 2004; 111:273-281.

174 Funderburg N, Lederman MM, Feng Z, Drage MG, Jadlowsky J, Harding CV, Weinberg A, Sieg SF: Human-defensin-3 activates professional antigen-presenting cells via Toll-like receptors 1 and 2. Proc Natl Acad Sci USA 2007;104:18631-18635.

-175 De Yang, Chen Q, Schmidt AP, Andersin GM, Wang JM, Wooters J, Oppenheim JJ, Chertov O: LL-37, the neutrophil granuleand epithelial cell-derived cathelicidin, utilizes formyl peptide receptor-like 1 (FPRL1) as a receptor to chemoattract human peripheral blood neutrophils, monocytes and T cells. J Exp Med 2000;192:10691074.

-176 Tjabringa GS, Ninaber DK, Drijfhout JW, Rabe KF, Hiemstra PS: Human cathelicidin LL-37 is a chemoattractant for eosinophils and neutrophils that acts via formyl-peptide receptors. Int Arch Allergy Immunol 2006;140:103-112.

177 Koczulla R, von Degenfeld G, Kupatt C, Krotz F, Zahler S, Gloe T, Issbrucker K, Unterberger P, Zaiou M, Lebherz C, Karl A, Raake P, Pfosser A, Boekstegers P, Welsch U, Heimstra PS, Vogelmeier C, Gallo RL, Clauss M, Bals R: An angiogenic role for the human peptide antibiotic LL-37/hCAP-18. J Clin Invest 2003;111:1665-1672.

178 Tjabringa GS, Aarbiou J, Ninaber DK, Drijfhout JW, Sorensen OE, Borregaard N, Rabe KF, Hiemstra PS: The antimicrobial peptide LL-37 activates innate immunity at the airway epithelial surface by transactivation of the epidermal growth factor receptor. J Immunol 2003;171:6690-6696.

179 Elssner A, Duncan M, Gavrilin M, Wewers MD: A novel $\mathrm{P} 2 \mathrm{X} 7$ receptor activator, the human cathelicidin-derived peptide LL37, induces IL-1 beta processing and release. J Immunol 2004;172:4987-4994.
180 Nagaoka I, Tamura H, Hirata M: An antimicrobial cathelicidin peptide, human CAP18/LL-37, suppresses neutrophil apoptosis via activation of formyl-peptide receptor-like 1 and P2X7. J Immunol 2006;176: 3044-3052.

181 Zhou L, Beuerman RW, Huang L, Barathi A, Foo YH, Li SF, Chea FT, Tan D: Proteomic analysis of rabbit tear fluid: defensin levels after an experimental corneal wound are correlated to wound closure. Proteomics 2007;7:3194-3206.

182 Kurpakus-Wheater M, Kernacki KA, Hazlett LD: Maintaining corneal integrity. How the 'window' stays clear. Prog Histochem Cytochem 2001;3:179-259.

183 Heilborn JD, Nilsson MF, Kratz G, Weber G, Sorensen O, Borregaard N, Stahle-Backdahl M: The cathelicidin antimicrobial peptide LL-37 is involved in re-epithelialization of human skin wounds and is lacking in chronis ulcer epithelium. J Invest Dermatol 2003;120:379-389.

184 Shaykhiev R, Beisswenger C, Kandler K, Senske J, Pucjner A, Damm T, Behr J, Bals R: Human endogenous antibiotic LL-37 stimulates airway epithelial cell proliferation and wound closure. Am J Physiol Lung Cell Mol Physiol 2005;289:L842-L848.

185 Redfern RL, Proske RJ, McDermott AM: Effect of defensins on corneal cell migration and cytokine production. Invest Ophthalmol Vis Sci 2004; 45:ARVO E-abstract 4866.

186 Li J, Beuerman R: Defensins augment the proinflammatory responses of human conjunctival epithelial cells. Invest Ophthalmol Vis Sci 2007;48:ARVO E-abstract 5312.

187 Li J, Shen JB, Tan D, Beuerman RW: Effect of HNP1 and HBD2 on cytokine gene expression in primary cultured human conjunctival epithelial cells. Invest Ophthalmol Vis Sci 2006;47:ARVO E-abstract 4377.

188 Li J, Raghunath M, Tan D, Lareu RR, Chen ZC, Beuerman RW: Defensins HNP1 and HBD2 stimulation of wound-associated responses in human conjunctival fibroblasts. Invest Ophthalmol Vis Sci 2006;47:38113819.

189 Gan L, Fagerholm P, Kim HJ: Effect of leukocytes on corneal cellular proliferation and wound healing. Invest Ophthalmol Vis Sci 1999;40:575-581.

190 Li Z, Burns A, Smith CW: Two waves of neutrophil emigration in response to corneal epithelial abrasion: distinct adhesion molecule requirements. Invest Ophthalmol Vis Sci 2006;47:1947-1955.

191 van den Berg RH, Faber-Krol MC, van Wetering S, Hiemstra PS, Daha MR: Inhibition of activation of the classical pathway of complement by human neutrophil defensins. Blood 1998;92:3898-3903. 
-192 Groeneveld TW, Ramwadhdoebe TH, Trouw LA, van den Ham DL, van der Borden V, Drijfhout JW, Hiemstra PS, Daha MR, Roos A: Human neutrophil peptide-1 inhibits both the classical and the lectin pathway of complement activation. Mol Immunol 2007;44:3608-3614.

193 Bhat S, Song YH, Lawyer C, Milner SM: Modulation of the complement system by human beta-defensin 2. J Burns Wounds 2007;5:e10.

194 Willcox MDP, Morris CA, Thakur A, Sack RA, Wickson J, Boey W: Complement and complement regulatory proteins in human tears. Invest Ophthalmol Vis Sci 1997;38: $1-8$.

-195 Prohaszka Z, Nemet K, Csermely P, Hudecz F, Mezo G, Fust G: Defensins purified from human granulocytes bind $\mathrm{Clq}$ and activate the classical complement pathway like the transmembrane glycoprotein gp41 of HIV. Mol Immunol 1997;34:809-816.

196 Prohasxka Z, Fust G: Contribution of complement to defensin action in eye. Lancet 1998;352:451-452.

$\checkmark 197$ Befus AD, Mowat C, Gilchrist M, Hu J, Solomon S, Bateman A: Neutrophil defensins induce histamine secretion from mast cells: mechanisms of action. J Immunol 1999; 163:947-953.

-198 Niyonsaba F, Someya A, Hirata M, Ogawa $\mathrm{H}$, Nagaoka I: Evaluation of the effects of peptide antibiotics human beta-defensins1/-2 and LL-37 on histamine release and prostaglandin $\mathrm{D}_{2}$ production from mast cells. Eur J Immunol 2001;31:1066-1075

199 Hamrah P, Dana MR: Corneal antigen-presenting cells. Chem Immunol Allergy 2007; 92:58-70.

-200 Chertov O, Michiel DF, Xu L, Wang JM, Tani K, Murphy WJ, Longo DL, Taub DD, Oppenheim JJ: Identification of defensin-1, defensin-2 and CAP37/azurocidin as T-cell chemoattractant proteins released from IL8 stimulated neutrophils. J Biol Chem 1996; 271:2935-2940.
201 Chaly YV, Paleolog EM, Kolesnikova TS, Tikhonov II, Petratchenko EV, Voitenok NN: Neutrophil alpha-defensin human neutrophil peptide modulates cytokine production in monocytes and adhesion molecule expression in endothelial cells. Eur Cytokine Netw 2000;11:257-266.

202 Boniotto M, Jordan WJ, Eskdale J, Tossi A, Antcheva N, Crovella S, Connell ND, Gallagher G: Human beta-defensin 2 induces a vigorous cytokine response in peripheral blood mononuclear cells. Antimicrob Agents Chemother 2006;50:1433-1441.

203 Zheng Y, Niyonsaba F, Ushio H, Nagaoka I, Ikeda S, Okumura K, Ogawa H: Cathelicidin LL-37 induces the generation of reactive oxygen species and release of humanalpha defensins from neutrophils. $\mathrm{Br}$ Dermatol 2007;157:1124-1131.

204 Bowdish DM, Davidson DJ, Speert DP, Hancock REW: The human cationic peptide LL-37 induces activation of the extracellular signal-regulated kinase and p38 kinase pathways in primary human monocytes. J Immunol 2004;172:3758-3765.

205 Chavakis T, Cines DB, Rhee JS, Liang OD, Schubert U, Hammes HP, Higazi AA, Nawroth PP, Preissner KT, Bdeir K: Regulation of neovascularisation by human neutrophil peptides (alpha-defensins): a link between inflammation and angiogenesis. FASEB J 2004;18:1306-1308.

206 Economopoulou M, Bdeir K, Cines BD, Fogt F, Bdeir Y, Lubkowski J, Lu W, Preissner KT, Hammes HP, Chavakis T: Inhibition of pathologic retinal neovascularisation by alpha-defensins. Blood 2005;106: 3831-3838.

207 Marr AK, Gooderham WJ, Hancock REW: Antibacterial peptides for therapeutic use: obstacles and realistic outlook. Curr Opin Pharmacol 2006;6:468-472.

208 Hancock REW, Sahl HG: Antimicrobial and host-defense peptides as new anti-infective therapeutic strategies. Nat Biotechnol 2006;24:1551-1557.
209 McPhee JB, Scott MG, Hancock REW: Design of host defence peptides for antimicrobial and immunity enhancing activities. Comb Chem High Throughput Screen 2005;8:257-272.

210 Liu S, Zhou L, Li J, Verma C, Foo YH, Yap EP, Tan DT, Beuerman RW: Linear analogues of human beta-defensin 3: concepts for design of antimicrobial peptides with reduced cytotoxicity to mammalian cells. Chembiochem 2008;9:964-973.

211 Nos-Barbera S, Portoles M, Morilla A, Ubach J, Andreu D, Paterson CA: Effect of hybrid peptides of cecropin A and melittin in an experimental model of bacterial keratitis. Cornea 1997;16:101-106.

212 Mannis M: The use of antimicrobial peptides in ophthalmology: an experimental study in corneal preservation and the management of bacterial keratitis. Trans Am Ophthalmol Soc 2002;100:243-271.

-213 Brandt CR, Akkarawongsa R, Altmann S, Jose G, Kolb AW, Waring AJ, Lehrer RI: Evaluation of a theta-defensin in a murine model of herpes simplex virus type 1 keratitis. Invest Ophthalmol Vis Sci 2007;48: 5118-5124.

214 Willcox M, Cole N, Lan J, Hume E, Aliwarga Y, Schubert T, Stapleton F, Sankaridurg $\mathrm{P}$ : Contact lenses coated with protamine reduce bacterial adhesion and the production of contact lens induced acute red eye (CLARE). Invest Ophthalmol Vis Sci 2004; 45:ARVO E-abstract 1568

215 Sousa LB, Mannis MJ, Schwab IR, Cullor J, Hosotani H, Smith W, Jaynes J: The use of synthetic cecropin (D5C) in disinfecting contact lens solutions. CLAO J 1996;22: 114-117.

-216 Schwab IR, Dries D, Cullor J, Smith W, Mannis M, Reid T, Murphy CJ: Corneal storage medium preservation with defensins. Cornea 1992;11:370-375. 